\title{
Pengaruh Model Pembelajaran Inkuiri Terbimbing Berbantuan Google Meet Terhadap Hasil Belajar Matematika Siswa Bahasan Aljabar
}

\author{
Oktavia Muhati ${ }^{*}$, John R. Wenas ${ }^{1}$, Patricia V.J. Runtu ${ }^{1}$
}

1Pendidikan Matematika, Fakultas Matematika dan Ilmu Pengetahuan Alam, Universitas Negeri Manado

*e-mail: oktaviahm@gmail.com

\begin{abstract}
ABSTRAK
Penelitian ini dilatarbelakangi masalah yang ditemukan saat melaksanakan PPL II di SMP Negeri 2 Tondano setiap pembelajaran guru berlangsungnya, guru masih memakai pembelajaran yang berpusat pada guru secara langsung, hal tersebut menyebabkan siswa malas belajar matematika dan hasil belajarnya tidak maksimal. Riset ini bertujuan buat menidentifikasi penerapan Model Pembelajaran Guided Inquiry berbantuan aplikasi Google Meet terhadap Hasil Belajar Matematika Siswa. Prosedur riset ini ialah eksperimental, dengan desain riset Randomized Subjects Posstest Only Control Group Design. Sampel diambil dari 2 kelas normal dan homogeny yakni kelompok VII A selaku kelompok Eksperimen serta VII B selaku kelompok kontrol oleh jumlah masing-masing 20 dan 21 siswa. Data penelitian dianalisis memakai uji-t dan didapatkan nilai thitung $=4.7115171135>t_{\text {tabel }}=1.684875$ dengan taraf nyata $\alpha=0.05$ artinya tolak $\mathrm{H}_{0}$ dan terima $\mathrm{H}_{1}$. Dengan demikian, penggunaan model pembelajaran Inkuiri Terbimbing berpengaruh terhadap Hasil Belajar Siswa.
\end{abstract}

Kata kunci: Model Pembelajaran Inkuiri Terbimbing, Hasil Belajar

\begin{abstract}
This research is motivated by the problems found when implementing PPL II at SMP Negeri 2 Tondano every time teacher learning takes place, teachers still use teacher-centered learning directly, this causes students to be lazy to learn mathematics and their learning outcomes are not optimal. This research aims to identify the application of the Guided Inquiry Learning Model assisted by the Google Meet application on Student Mathematics Learning Outcomes. This research procedure is experimental, with a research design of Randomized Subjects Posttest Only Control Group Design. Samples were taken from 2 normal and homogeneous classes, namely group VII $A$ as the Experiment group and VII B as the control group by a total of 20 and 21 students, respectively. The research data were analyzed using a t-test and the value of $t_{\text {count }}=4.7115171135>t_{\text {table }}=1.684875$ with a real level $\alpha=0.05$ which means reject $H_{0}$ and accept $H_{1}$. Thus, the use of the Guided Inquiry learning model affects Student Learning Outcomes.
\end{abstract}

Keywords: Guided Inquiry Learning Model, Learning Outcomes

\section{PENDAHULUAN}

Generasi muda harus dibekali dengan adanya pendidikan untuk menyiapkan mereka menjadi manusia yang dapat bersaing di masa digital seiring dengan perkembangan IPTEK. Pendidikan dimaksud selaku proses pengubahan sikap seorang ataupun kalangan orang selama proses mendewasakan manusia lewat jalan pengajaran serta bimbingan, prosedur pembentukan serta teknik mendidik Untuk upaya menanamkan nilai-nilai karakter (Kemendikbud, 2012). Pendidikan itu sangat penting untuk dipelajari begitu juga dengan pendidikan matematika yang harus ditingkatkan, sebab matematika ialah dasar dari ilmu pengetahuan lain. Pendidikan Matematika sendiri dari Depdiknas mempunyai tujuan untuk menguasai konsep matematika, memecahkan permasalahan, memakai penalaran, mengkomunikasikan gagasan, serta mempunyai perilaku menghargai manfaat matematika dalam kehidupan yang dilansir oleh (Fadjar, 2014). Oleh sebab itu, butuh kerja keras untuk mengarahkan matematika dengan metode yang terbaik untuk tingkatkan kemampuan materi matematika. Diharapkan hasil belajar matematika siswa bisa meningkat.

Menurut Piaget dalam (Sanjaya, 2016), pengetahuan itu akan bermakna manakalah dicari dan ditemukan sendiri oleh siswa. (Rustaman, 2005) juga menyatakan bahwa esensi dari 
pembelajaran inkuiri adalah untuk mengelola kondisi atau lingkungan belajar siswa, dengan bimbingan yang cukup dalam menemukan prinsip atau konsep ilmiah.

Aspek yang pengaruhi hasil belajar matematika bisa berasal dari siswa, guru, alat, serta lingkungan. Aspek dari siswa ialah keaktifan siswa, bagaimana siswa menampilkan semangat yang positif, jiwa mengolah data, tidak hanya menyimpan data tanpa melaksanakan transformasi (Rusman, dkk, 2011). Penguasaan hasil belajar seseorang dapat dilihat dari perilakunya, baik perilaku dalam penguasaan pengetahuan, keterampilan berpikir maupun keterampilan motorik. Hampir sebagian besar dari kegiatan atau perilaku yang diperlihatkan seseorang merupakan hasil belajar (Sukmadinata, 2009). Penyebab berikutnya datang dari guru ialah strategi yang digunakan guru tidak inovatif, model tidak berganti ataupun guru belum memahami materi.

Bersumber pada hasil observasi disaat melakukan PPL II di Sekolah Menengah Pertama (SMP) Negeri 2 Tondano setiap berlangsungnya proses pembelajaran guru masih memakai pembelajaran langsung. Aktivitas pembelajaran masih berpusat pada guru, guru cuma menerangkan materi-materi saja sehingga siswa kurang termotivasi untuk belajar. Kondisi tersebut hendak membuat siswa malas belajar matematika serta menyebabkan hasil belajar matematika siswa belum optimal. Pembelajaran langsung dapat berbentuk ceramah, demonstrasi, pelatihan atau praktek dan kerja kelompok (Trianto,2007).

Untuk mengatasi permasalahan tersebut, guru butuh memilih model pembelajaran yang bisa menghasilkan suasana pembelajaran yang mengasyikan serta mengaitkan siswa secara aktif. Tukar pikiran yang terjadi tidak hanya sebagai cara komunikasi antar guru, supaya siswa bisa menguasai bahan ajar dengan baik. Model pendidikan inkuiri terbimbing ialah model pendidikan yang bisa dipilih buat menghasilkan pembelajaran yang menarik serta mengajak seluruh siswa berpartisipasi aktif dalam pembelajaran (Gumay, 2014). Diharapkan dengan dorongan semangat belajar siswa bisa terbentuk proses pembelajaran yang menarik serta minat belajar siswa bisa bertambah sehingga bisa meningkatkan hasil belajar (Suwangsih \& Tiurlina, 2010).

Dalam suasana pandemi Covid-19 disaat ini guru dituntut untuk tetap melakukan pembelajaran yang dibantu dengan sebagian media pembelajaran berbasis online, salah satunya memakai Google Meet untuk melaksanakan pembelajaran dengan bertatap muka secara virtual antara guru dengan siswa (Sarwiti, D. 2020). Dengan Google Meet, siswa juga dapat berinteraksi, menghasilkan suasana belajar yang mengasyikan, dan mendorong siswa buat berperan aktif sehingga menaikkan hasil belajar siswa.

Bersumber pada penjelasan diatas, maka penulis tertarik melaksanakan riset dengan mempraktikan model pembelajaran Inkuiri Terbimbing yang dikombinasikan dengan pemakaian Google Meet untuk menaikkan hasil belajar siswa. Dengan demikian penelitian ini berjudul "Pengaruh Model Pembelajaran Inkuiri Terbimbing Berbantuan Google Meet Terhadap Hasil Belajar Matematika Siswa Bahasan Aljabar"

\section{METODE}

Penelitian yang dilakukan merupakan penelitian eksperimen semu. Selama riset ini dicoba di SMP Negeri 2 Tondano. Saat riset dilakukan selama bulan November semester ganjil tahun ajaran 2020/2021. Populasi dalam riset ini merupakan segala peserta didik kelas VII SMP Negeri 2 Tondano tahun ajaran 2020/2021 yang terdiri dari tujuh kelas. Untuk contoh dalam penelitian dipilih dua kelompok secara acak dari tujuh kelompok, dimana satu kelompok selaku kelompok eksprerimen serta yang lain selaku kelompok kontrol.

Variabel bebas selama riset ini yaitu Model Pembelajaran Inkuiri Terbimbing untuk kelompok eksperimen serta pembelajaran Direct Instruction untuk kelompok kontrol. Sementara Variabel terikat atas riset ialah hasil belajar siswa (nilai post-test setelah diberi perlakuan). Tipe penelitian eksperimen melalui pola rancangan Randomized Subjects Posstest Only Control Group Design. 
Tabel 1. Rancanganpenelitian

\begin{tabular}{clcc}
\hline & Kelompok & Perlakuan & Postes \\
\hline (R) & Eksperimen & $\mathrm{X}_{1}$ & $\mathrm{Y}_{2}$ \\
\hline (R) & Kontrol & $\mathrm{X}_{2}$ & $\mathrm{Y}_{2}$ \\
\hline
\end{tabular}

Bersumber pada Tabel 1 bisa dilihat kalau rancangan selama penelitian ini ialah dengan memberikan perlakuan atas kelompok ekperimen serta kelompok kontrol, pada kelompok eksperimen diberikan perlakuan $\mathrm{X}_{1}$ ialah memakai model inkuiri terbimbing berbantuan aplikasi google meet sedangkan kelompok kontrol diberikan perlakuan $\mathrm{X}_{2}$ ialah seraya memakai model direct instruction berbantuan aplikasi google meet. Kedua diberikan posttest buat memandang hasil belajar siswa akan perlakuan yang diterapkan. Instrumen penelitian yang digunakan pada penelitian ini merupakan tes tertulis bentuk uraian yang telah diuji terlebih dahulu dengan validitas isi.

\section{HASIL DAN PEMBAHASAN}

Data penelitian diambil dari dua kelompok ialah kelompok VII A selaku kelompok eksperimen yang berjumlah 20 siswa serta kelompok VII B selaku kelompok kontrol yang berjumlah 21 siswa. Data ini diambil dari hasil posttest materi Bentuk Aljabar dengan rentang nilai $0-100$.

Tabel 2. Statistik nilai posttest kelas eksperimen dan kelas Kontrol

\begin{tabular}{cccc}
\hline \multirow{2}{*}{ No } & \multirow{2}{*}{ Statistik } & \multicolumn{2}{c}{ Nilai Statistik } \\
\cline { 3 - 4 } & & Kelas Eksperimen & Kelas Kontrol \\
\hline 1 & Jumlah & 1404 & 1226 \\
\hline 2 & Nilai Min & 48 & 45 \\
\hline 3 & Nilai Max & 88 & 76 \\
\hline 4 & Rata-rata & 70.2 & 58.38095238 \\
\hline 5 & S. deviasi & 10.23718711 & 8.200464563 \\
\hline 6 & Varians & 104.8 & 67.24761905 \\
\hline
\end{tabular}

Bersumber dari Tabel 2 dapat dilihat kalau rata-rata hasil posttest atas kelompok eksperimen adalah 70.2 dengan nilai minimum 48. Kemudian pada kelas kontrol rata-rata hasil posttest menjadi 58.38095238 dengan nilai minimal 45.

Uji normalitas data pada riset ini memakai uji liliefors yang diolah menggunakan software Microsoft Excel. Hasil uji normalitas dari Posttest pada kelas eksperimen menunjukkan nilai $L_{\text {hitung }}=0,065589596$ serta $L_{\text {tabel }}=0,192$, karena $L_{\text {hitung }}<L_{\text {tabel }}$ maka terima $H_{0}$ dan data tersebar normal. Sementara uji normalitas dari Posttest pada kelompok control menunjukkan nilai $L_{\text {hitung }}=0,1856519$ dan $L_{\text {tabel }}=0,1881$, karena $L_{\text {hitung }}<L_{\text {tabel }}$ maka terima $H_{0}$ dan data tersebar normal.

Hasil penjabaran pengujian kesamaan dua varians/macam dengan statistik uji $F$ atas data beda posttest dengan $s_{E}^{2}=104,8$ serta $s_{K}^{2}=67,247619$ memberikan nilai $F_{\text {hitung }}=1,55841949$ sedangkan nilai $F_{\text {tabel }}=f_{0,05(20,21)}=2,13700896$ maka terima $H_{0}: \sigma_{1}^{2}=\sigma_{2}^{2}$. Jadi, bisa dilihat kalau varians dari kedua kelas eksperimen serta kontrol merupakan homogen ataupun sama. Uji prasyarat ini dilakukan berdasarkan panduan tentang pengujian perbandingan rata-rata dua kelompok tidak berpasangan (uji t tidak berpasangan) yang diadaptasi dari (Lolombulan, 2017).

Dari hasil pengujian hipotesis selama memakai uji-t pada taraf nyata $\alpha=0,05$ didapat $t_{\text {hitung }}=4,711517135$ serta nilai $t_{\text {tabel }}=t_{0.05(39)}=1.684875$ yang maksudnya statistik uji tersebut jatuh dalam daerah kritis. Bersumber pada kriteria pengujian hipotesis ialah tolak $H_{0}$ apabila uji statistik masuk dalam area kritis hingga bisa disimpulkan kalau rata-rata hasil belajar siswa yang memakai model pembelajaran inkuiri terbimbing berbantuan aplikasi google meet lebih dari rata-rata hasil belajar siswa dengan memakai pembelajaran direct instruction. 
Bersumber pada studi yang dilakukan di kelas VII A serta VII B SMP Negeri 2 Tondano pada semester ganjil tahun ajaran 2020-2021 bentuk materi Aljabar dapat dilihat pada perbandingan hasil dikelas eksperimen serta dikelas kontrol. Dari Kelompok eksperimen pembelajaran diterapkan dengan model inkuiri terbimbing berbantuan aplikasi google meet yang secara universal menampilkan pengaruh positif dalam pembelajaran matematika. Perihal ini ditunjukan untuk rata-rata hasil uji yang diberikan atas kedua kelompok, dimana nilai posttest kelompok eksperimen lebih besar dari nilai posttest kelompok kontrol. Dengan begitu menunjukan bahwa pengunaan model pembelajaran inkuri terbimbing berbantuan aplikasi google meet lebih baik dibandingkan dengan mengajarkan materi secara direct instruction.

\section{KESIMPULAN}

Berdasarkan hasil penelitian dan beberapa penjelasan diatas sehingga dapat ditarik suatu kesimpulan bahwa hasil belajar siswa yang diajarkan menggunakan model pembelajaran inkuiri terbimbing dan hasil belajar siswa yang memakai pembelajaran langsung atau direct instruction dianalisis dengan memakai uji-t didapatkan nilai $t_{\text {hitung }}=4.7115171135>t_{\text {tabel }}=1.684875$ dengan taraf nyata yang digunakan $\alpha=0.05$. Karena data penelitian artinya tolak $\mathrm{H}_{0}$ dan terima $\mathrm{H}_{1}$, maka penggunaan model pembelajaran Inkuiri Terbimbing berpengaruh terhadap hasil belajar siswa.

\section{DAFTAR PUSTAKA}

Fadjar, S. (2014). Pembelajaran Matematika: Cara Meningkatkan Kemampuan Berpikir Siswa. Yogyakarta: Graha Ilmu.

Gumay, T. (2014). Penerapan Metode Inkuiri Terbimbing untuk Meningkatkan Hasil Belajar Fisika Siswa Kelas VIII.6 Pada Konsep Bumi diSMP Negeri 3 Kota Bengkulu. Bengkulu: Fakultas Keguruan dan Ilmu Pnedidikan Universitas Bengkulu.

Kemendikbud. (2012). Pengembangan Kurikulum 2013. Jakarta: Kementrian Pendidikan dan Kebudayaan.

Lolombulan, H. J. (2017). Statistika Bagi Peneliti Pendidikan. Yogyakarta: Andi.

Rusman, dkk. (2011). Pembelajaran Berbasis Teknologi Informasi dan Komunikasi (Mengembangkan Profesinalitas Guru). Jakarta: Rajawali Pers.

Rustaman, N. (2005). Perkembangan Penelitian Pembelajaran berbasis Inkuiri Dalam Pendidikan Sains (Makalah dipresentasikan dalam seminar Nasional II Himpunan Ikatan Sarjana dan Pemerhati Pendidikan IPA Indoensia Bekerja sama dengan FPMIPA UPI). Bandung.

Sanjaya, W. (2016). Strategi Pembelajaran Berorientasi Standar Proses Pendidikan. Jakarta: Kencana.

Sukmadinata, N. S. (2009). Landasan Psikologi Prose Pendidikan. Bandung: PT Rosdakarya.

Suwangsih, E., \& Tiurlina. (2010). Model Pembelajaran Matematika. Bandung: UPI Press.

Sarwiti, D. (2020). Penggunaan Google Meet Untuk Work Frome Home Di Era Pandemi Coronavirus Disease 2019 (Covid- 19). Jurnal Pengabdian Masyarakat, 13-21.

Trianto. (2007). Model-Model Pembelajaran Inovatif Berorintasi Kontuktivisme. Jakarta: Prestasi Pustaka. 